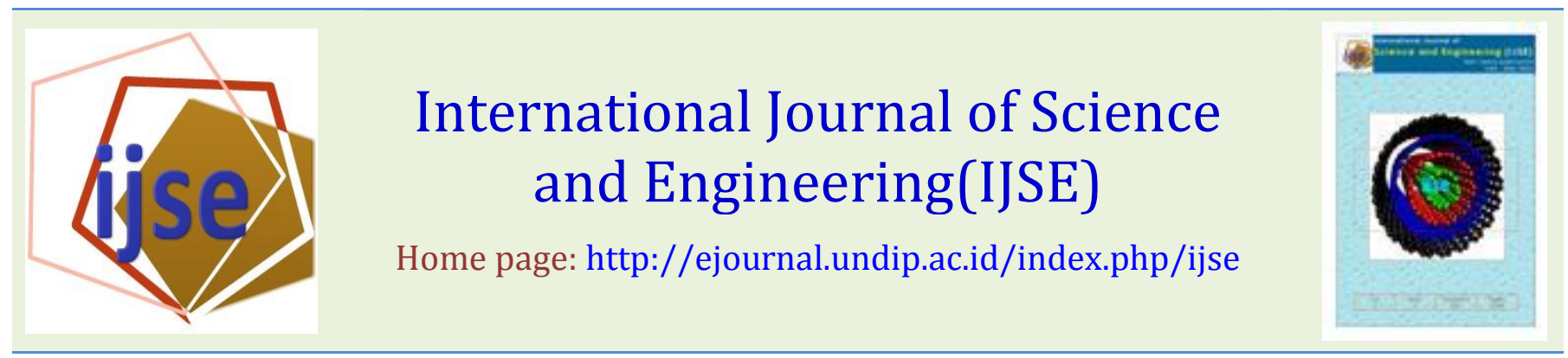

\title{
Condition and The Affecting Factors of Tanjung Jumlai Patch Reef in North Penajam Paser Regency East Kalimantan
}

\author{
Muchlis Efendi ${ }^{1}$, Sahat Hutahaean ${ }^{2}$, Anugrah A Budiarsa ${ }^{1}$ and T Hanjoko ${ }^{1}$ \\ 1)Fisheries and Marine Science Faculty of Mulawarman University, Kampus Gunung Kelua Samarinda, East Kalimantan 75123 \\ 2)Chevron Indonesia Company, Indonesia
}

Email:aditarm83@gmail.com

\begin{abstract}
Patch reef of Tanjung Jumlai which located in North Penajam Paser Regency, East Kalimantan Province has being suffered from stress and degradation, less studied and managed. Thus, this research was conducted to obtain data concerning on the reef condition and the affecting factors. The research was carried out from December 10-14, 2013. There were eight observation stations that surveyed using life form line intercept transect method to obtain data related with coral reef condition based on percent cover of live coral (LC) and coral mortality index (MI). The result showed that the lowest LC was 5\% at ST 7 (poor/bad coral condition) and the highest LC was 78\% (excellent condition), and the average LC was $42.5 \%$ (fair/moderate condition). The average coral mortality index was 0.34 with the lowest MI was 0.06 at ST 6 and the highest MI was 0.78 at ST 7 . This study also found that anthropogenic factors (mainly from Balikpapan Bay) were more influential toward the reef condition of Tanjung Jumlai patch reef rather than nonanthropogenic factors.

Keywords - Condition, Coral, Life form, Mortality Index, Patch Reef, Tanjung Jumlai

Submission: May 14, $2014 \quad$ Correction: June 25, 2014

Doi: 10.12777 /ijse.7.1.95-99

[How to cite this article: Muchlis Efendi, Sahat Hutahaean, Anugrah A Budiarsa and T Hanjoko. 2014. Condition and The Affecting Factors of Tanjung Jumlai Patch Reef in North Penajam Paser Regency East Kalimantan, International Journal of Science and Engineering, 7(1),95-99]. Doi: $10.12777 /$ ijse.7.1.95-99
\end{abstract}

\section{INTRODUCTION}

North Penajam Paser Regency is one of regencies in East Kalimantan Province that has sea as it direct border or part of the administration territory. North Penajam Paser Regency is relatively a young region in East Kalimantan Province that officially established in 2002, formerly was a district in Paser Regency (now as it's the south border). Waters boundaries areas of North Penajam Regency are: Makassar Strait at east and Balikpapan Bay at north (this bay also as the south border of Balikpapan City).

Sea waters area in this region consist of two groups of sandbars, i.e.: sandbar of Central Tanjung or also known as Gosong Saloloang and sandbar of Tanjung Jumlai at Kampung Baru Sub-District ("gosong" is Indonesian term for sandbar, sandbank, or shoal).

According to Jamal (2010), there was no specific effort of management or monitoring for the reef at the sandbars before the year of 2000, even when the surrounding activities became more intensive causing stress or damage to reefs at the sandbar.
Moreover, as the development acceleration in this region, this area also suffers the degradation of environment quality which caused by activities that directly influences the coral reef and/or the activities that takes place along the land and water of Balikpapan Bay.

In the implementation of monitoring and management of coral reef at the sandbars, stakeholders including government, company, NGO, university and community have not used their maximum effort. Moreover, the monitoring and management is not conducted in integrated way. Thus, database of coral reef existence and status at Tanjung Jumlai is limited.

Coral reef ecosystem is one of coastal and confines sea ecosystems with high primer productivity and has important role, such as: fishing ground, spawning ground, nursery ground, feeding ground, prevent coastal area from abrasion or degradation, raw material supplier, recreation, and so on. This ecosystem obviously has important role for the marine life, sea, coastal environment, and the human life (Anonymous, 2001). 
According to the situations mentioned above, it is obviously seen that coral reef in Tanjung Jumlai had suffered from stress and degradation which significantly affected the biota and humankind living around the area. Thus, this research was conducted to collect data of coral reef condition and the affecting factor particularly at sandbar of Tanjung Jumlai. The data was then used as database for following research and also to support the efforts of policy determination and management of coral reef in Tanjung Jumlai.

\section{RESEARCH METHOD}

The field data collection was conducted in waters of Tanjung Jumlai sandbar, Kampung Baru Sub-district, Penajam District, North Penajam Paser Regency from December 10 - 14, 2013.

This research used 8 (eight) observation stations, the first 4 stations were located at reef edge facing offshore or Makassar Strait, and the other 4 stations facing the mainland or Kalimantan (fig. 1)..
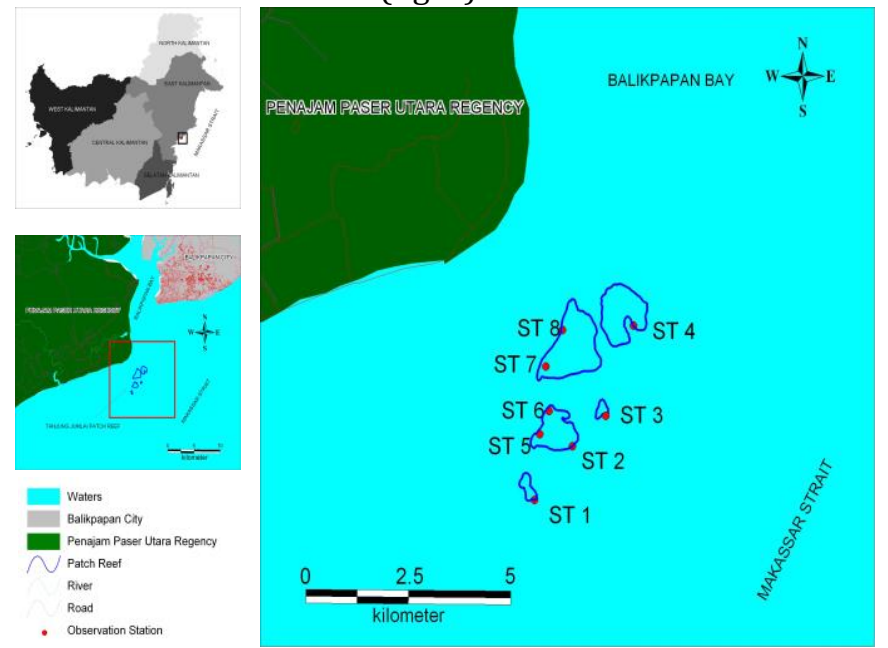

Figure 1. Sketch of Observation Stations at Patch Reef of Tanjung Jumlai.

According to English et al. (1994), the survey method that applied to collect data of coral reef condition was life form line intercept transect. Survey was performed by placing a $50 \mathrm{~m}$ measuring tape along the coral reef edge profile. Each coral colony or benthic organism that was crossed over by the line was measured by the length of each life form category. Categories of life form and codes that were used in this research are shown in Table 1.

The collected data was then calculated in order to obtain the percent cover of each life form using equation formulated by Gomez and Yap (1988), English, et al (1994) and Gomez, et al (1994):

$$
\text { PercentCover } \alpha=\frac{\text { total lengthof lifeform } \alpha}{\text { lengthof transect }} \times 100
$$

Percent cover of hard coral (HC) is total of both coverage of Acropora and Non-Acropora life form. Live coral coverage (LC) is total of hard coral cover and soft coral cover $(\mathrm{LC}=\mathrm{HC}+\mathrm{SC}$ ). The percentage of $\mathrm{LC}<25 \%$ is categorized as "poor/bad" coral coverage condition, 25\% $<\mathrm{LC}<50 \%$ is categorized as "fair/moderate" condition, $50 \%<\mathrm{LC}<75 \%$ is categorized as "good" condition, and LC $\geq 75 \%$ is categorized as "excellent" condition (Jompa and Pet-Soede, 2002; Hill and Wilkinson, 2004). Coral mortality index (MI) is calculated as ratio of standing dead coral to total cover of both live and dead coral, MI = dead coral/(live coral + dead coral). Coral mortality index value near to zero indicates no significant changes of live coral, while the value of 1 shows that there is a change of live to dead coral, and if MI $>0.33$, the mortality index is considered high and the reef is classified as sick (Sadhukhan and Raghunathan, 2011).

Table 1. Categories of Life form and Codes.

\begin{tabular}{ll}
\hline Categories/Lifeform & Code \\
\hline DEAD CORAL & \\
Dead Coral & DC \\
Dead Coral with Algae & DCA
\end{tabular}

\section{HARD CORAL}

Acropora

\begin{tabular}{|c|c|c|}
\hline Acropora Bran & ig Coral & ACB \\
\hline Acropora Tabu & Coral & ACT \\
\hline Acropora Encr & ng Coral & ACE \\
\hline Acropora Subn & sive Coral & ACS \\
\hline Acropora Digit & Coral & ACD \\
\hline Non-Acropora & Branching & \\
\hline Coral & & CB \\
\hline $\begin{array}{l}\text { Non-Acropora } \\
\text { Coral }\end{array}$ & Encrusting & CE \\
\hline Non-Acropora & iose Coral & CF \\
\hline Non-Acropora & ssive Coral & CM \\
\hline Non-Acropora & Submassive & \\
\hline Coral & & CS \\
\hline Non-Acropora & Mushroom & \\
\hline Coral & & CMR \\
\hline Non-Acropora & lepora Coral & CME \\
\hline Non-Acropora & Heliopora & \\
\hline Coral & & CHL \\
\hline
\end{tabular}

OTHER FAUNA

$\begin{array}{ll}\text { Soft Coral } & \text { SC } \\ \text { Sponge } & \text { SP } \\ \text { Zoanthids } & \text { Z0 } \\ \text { Others } & \text { OT } \\ \text { Algae: Algal Assemblage } & \text { AA } \\ \quad \text { Coralline Algae } & \text { CA } \\ \quad \text { Halimeda } & \text { HA } \\ \text { Macroalgae } & \text { MA } \\ \text { Turf Algae } & \text { TA }\end{array}$

ABIOTIC

$\begin{array}{ll}\text { Sand } & \text { S } \\ \text { Rubble } & \text { R } \\ \text { Rock } & \text { RCK } \\ \text { Silt } & \text { SI } \\ \text { Water } & \text { WA } \\ & \text { DDD }\end{array}$

Missing Data

Source: English et al. (1994)

\section{III.RESULT AND DISCUSSION}

Sandbar of Tanjung Jumlai is located about $1.3 \mathrm{nmi}$ southeast seaward of Kampung Baru Sub-district shoreline, North Penajam Paser Regency. The sandbar width is estimated about 346.58 ha which consists of five spot of sandbars, i.e.: $150.7,103.7,70.73,13.45$, and 8.0 ha. Based on the type of formation, coral reef of Tanjung Jumlai is categorized as patch reef type; therefore, from this point, the author mentions the reef at Tanjung Jumlai sandbar as patch reef of Tanjung Jumlai. 
The coral at this patch reef develops well along the reef edge follows a narrow line trend at $\pm 7 \mathrm{~m}$ depth which measured from seawater surface level (or zero meter) until seaward margin. It grows optimal and in dense coverage at reef crest of $\pm 1-3 \mathrm{~m}$ deep. Based on the observation result, the dominant life form was acropora branching (ACB), acropora tabulate (ACT), and nonacropora foliose (CF) from category of $\mathrm{HC}$, while sand (S) and rubble (R) as the dominant substrate or abiotic category. The domination of coral such as branching and tabulate acroporids life form at reef crests was due to fastgrowing scleractinians and its abundance at high energy environment (Tomascik et al., 1997).

The result of analysis shows that percent cover LC varies from 5 - 78\% which categorized as poor/bad until excellent condition. The lowest LC was observed at station 7 (ST 7) by LC=5.0\% which categorized as poor $/$ bad condition and dominated by vast sand coverage. Meanwhile, the highest live coral coverage was observed at station 6 (ST 6 ) by $\mathrm{LC}=78.0 \%$ which categorized as excellent condition and dominated by non-acropora foliose life form. In general, all observed station was categorized as fair/moderate coral condition which indicated by live coral coverage $42.5 \%$.

Domination of a certain life form occurred especially at station with very high live coral coverage, the stations were: ST 2 with $\mathrm{LC}=64.8 \%$ which dominated by acropora brancing life form with $\mathrm{ACB}=50 \%$, ST 5 with $\mathrm{LC}=66.7 \%$ which dominated by acropora tabulate (ACT $=24.4 \%$ ), and ST 6 with LC $=78 \%$ which dominated by non-acropora foliose $(\mathrm{CF}=41.4 \%)$. This condition is similar to what had been written by Edinger and Risk (2000) that site with very high percentage of live coral cover is frequently composed by large mono-specific stands of coral.

The reefs of station ST 2, ST 5, and ST 6 have better coverage coral than others stations. This condition was due to the location of patch reef which relatively surrounded by others four patch reefs (fig.1). The incoming waves which flows from sea or Makassar Strait is prevented by patch reef of station ST 1 and ST 2, while the heavy loads caused by sediment particles from Balikpapan Bay is prevented by patch reef of ST 4, ST 7, and ST 8.

The value of coral mortality index ranged from 0.06 (ST 6) till 0.78 (ST 7). Meanwhile, the average MI of all stations was 0.34 and this value was above the limit of index classifying sick reef condition.

Low MI value was obtained from stations of ST 2, ST, 5, ST 6 and ST 8 which indicated healthy reef condition, and it inversely correlated to the value of LC except for ST 8. At ST 8 , the live coral coverage ( $\mathrm{LC}=28 \%$ ) was categorized into fair/moderate. However, no significant changes of live coral recorded in ST 8 as the MI value was 0.19 . This phenomenon, according to Table 2, demonstrated that the loss of live coral coverage wasn't only because of mortality transformation into standing dead coral but also caused by further damage into rubble and/or rubble covered by algae as indicated that this station consisted the highest rubble coverage $(\mathrm{R}=35.4 \%)$. According to Jamal (2010), the change of live coral to rubble in this area might be due to destructive fishing method especially explosive fishing where the explosion will shatter all coral into small fractures. This condition was found at ST 6 (the second highest rubble coverage) where the location is at the nearest side to the mainland making it as the easiest reachable point amongst others Tanjung Jumlai patch reefs.

High MI value was obtained from station of ST 1, ST 3, ST 4, and ST 7. The seaward position of ST 1 and ST 3, especially the part of reef crest and fore reef, will receive direct impact of waves. During July till September, normally when in southeast monsoon period, there is strong wind blowing from Java/Flores Sea passing through along Makassar Strait to Sulawesi Sea (Tomascik et al., 1997). During this period, waves will come from south and southeast, and directly hit the seaward side of Tanjung Jumlai patch reef, in this research ST 1 and ST 3. In other side, high mortality index represented from ST 4 and ST 7 was also assumed due to the position at the patch reef of Tanjung Jumlai. Those stations as well as ST 8, was the nearest point to the mainland, thus easier exposed to human activities impact.

There are some factors influencing the coral reef condition at patch reef of Tanjung Jumlai. The factor could come from both anthropogenic (human) and nonanthropogenic (nature), some of those had been mentioned previously.

The hydrodynamic plays both positive and negative impact to the reef. Normally, the water movement could help washing the sediment particle from the coral polyp and substratum and also carry nutrient to the reef, but at some period mostly during the southeast monsoon, rough sea condition could possibly cause physical damage to the coral structure or the underwater turbulence could change high turbidity and water temperature.

Tides also affect and limit the coral growth and development in this patch reef. Besides generating water movement, the condition at low tides could increase surface water temperature or direct air exposure for the coral particularly at reef crest. The influence of high water temperature is mainly indicated by bleached coral observed during the research.

The influence that comes from Balikpapan Bay and mainland is mostly generated by human activities. Erosion and Sedimentation Working Group (2002) and Sinaga et al. (2013) mentioned that river systems in Balikpapan Bay suffer bio geophysical disturbance as high concentration of turbidity and sediment loads which mainly caused by land development and conversion for industrial, residence, mining, plantation, mangrove conversion area, etc.

This high turbidity and sediment loads in the water body of Balikpapan Bay, will be transported to Tanjung Jumlai patch reef area by current movement. Arriving to coral reef area, turbidity and sediment particle in the water column: 1) Directly cover the coral structure thus buried the coral polyp, 2) transform the substrate composition into softer that deplete the chance of new coral recruitment at the area because typically the attachment of coral require hard object or substrate, and 3) particularly for sediment particle in water column, they could decrease the sunlight penetration into the water thus limiting the coral colony development because zooxanthellae mutualism in coral organism requires 
sunlight for the photosynthesis process. All those factors caused coral reef at Tanjung Jumlai patch reef was only found till $\pm 7 \mathrm{~m}$ depth and below that deep the sunlight intensity was very low, lot dissolved sediment particles and lot of mud in the bottom substrate.

Table 2. Percent Cover of Life Form at Each Observed Station and in Average of Tanjung Jumlai Patch Reef .

\begin{tabular}{|c|c|c|c|c|c|c|c|c|c|c|}
\hline \multirow{2}{*}{\multicolumn{2}{|c|}{ Categories/Life form }} & \multicolumn{9}{|c|}{ Station } \\
\hline & & \multirow{2}{*}{$\frac{\text { ST } 1}{9.8}$} & \multirow{2}{*}{$\frac{\text { ST } 2}{0}$} & \multirow{2}{*}{$\frac{\text { ST } 3}{25.4}$} & \multirow{2}{*}{$\begin{array}{ll}\text { ST } 4 & \\
& 0\end{array}$} & \multirow{2}{*}{$\begin{array}{r}\text { ST } 5 \\
0\end{array}$} & \multirow{2}{*}{ ST 6} & \multirow{2}{*}{$\begin{array}{ll}\text { ST 7 } & \\
& 0\end{array}$} & \multirow{2}{*}{$\frac{\text { ST } 8}{0}$} & \multirow{2}{*}{$\frac{\text { Average }}{4.4}$} \\
\hline DFAD CORAI & DC & & & & & & & & & \\
\hline & DCA & 27.6 & 15.2 & 8.4 & 43.0 & 13.7 & 5.1 & 18.1 & 6.4 & 17.2 \\
\hline \multirow{5}{*}{ ACROPORA } & ACB & 9.2 & 49.98 & 11.2 & 0 & 6.6 & 10.9 & 1.1 & 12.5 & 12.7 \\
\hline & ACT & 0.8 & 4.82 & 3.0 & 0 & 24.4 & 2.6 & 1.6 & 2.0 & 4.9 \\
\hline & ACE & 0 & 6.2 & 0 & 0 & 0 & 0 & 0 & 0 & 0.8 \\
\hline & ACS & 5.6 & 0 & 0 & 1.4 & 0 & 0 & 0 & 0 & 0.9 \\
\hline & ACD & 0 & 0 & 0 & 0 & 0 & 0 & 0 & 0.3 & 0 \\
\hline \multirow{8}{*}{ NON ACROPORA } & $\mathrm{CB}$ & 0 & 3.8 & 6.4 & 0 & 11.6 & 5.0 & 0 & 0 & 3.4 \\
\hline & $\mathrm{CE}$ & 0 & 0 & 0.6 & 3.4 & 5.2 & 4.6 & 0.7 & 5.5 & 2.5 \\
\hline & $\mathrm{CF}$ & 0 & 0 & 5.4 & 0 & 4.2 & 41.4 & 0 & 3.3 & 6.8 \\
\hline & $\mathrm{CM}$ & 17.6 & 0 & 4.4 & 14.2 & 0.1 & 4.4 & 0.9 & 1.6 & 5.4 \\
\hline & $\mathrm{CS}$ & 0 & 0 & 0.4 & 0 & 8.2 & 0.6 & 0.1 & 2.4 & 1.5 \\
\hline & CMR & 0 & 0 & 7.2 & 0 & 1.0 & 4.3 & 0 & 0.4 & 1.6 \\
\hline & CME & 0 & 0 & 0 & 0 & 0.1 & 0 & 0.6 & 0 & 0.1 \\
\hline & CHL & 2.6 & 0 & 0 & 0 & 5.3 & 3.8 & 0 & 0 & 1.5 \\
\hline \multirow{9}{*}{ OTHER FAUNA } & SC & 3.8 & 0 & 0 & 0 & 0 & 0.4 & 0 & 0 & 0.5 \\
\hline & SP & 4 & 0 & 0 & 0 & 2.0 & 0 & 0.9 & 4.9 & 1.5 \\
\hline & AA & 0 & 0 & 0 & 0 & 1.6 & 0 & 0 & 2 & 0.5 \\
\hline & $\mathrm{CA}$ & 0 & 0 & 0 & 0 & 0.5 & 0 & 0 & 0 & 0.1 \\
\hline & HA & 0 & 0 & 0 & 0 & 0 & 0 & 0 & 0 & 0 \\
\hline & MA & 0 & 0 & 0 & 0 & 0 & 0 & 0 & 0 & 0 \\
\hline & $\mathrm{TA}$ & 0 & 0 & 0 & 0 & 0 & 0 & 0 & 0 & 0 \\
\hline & $\mathrm{ZO}$ & 0 & 0 & 0 & 0 & 0 & 0 & 0 & 0 & 0 \\
\hline & OT & 0 & 0 & 0 & 0 & 1.7 & 0 & 0.2 & 0 & 0.2 \\
\hline \multirow{5}{*}{ ABIOTIC } & S & 19.0 & 11.8 & 25.0 & 38.0 & 0 & 0 & 48.4 & 1.4 & 18.0 \\
\hline & $\mathrm{R}$ & 0 & 8.2 & 2.6 & 0 & 12.9 & 16.9 & 27.4 & 35.4 & 12.9 \\
\hline & RCK & 0 & 0 & 0 & 0 & 0 & 0 & 0 & 0 & 0 \\
\hline & SI & 0 & 0 & 0 & 0 & 0.9 & 0 & 0 & 21.9 & 2.9 \\
\hline & WA & 0 & 0 & 0 & 0 & 0 & 0 & 0 & 0 & 0 \\
\hline
\end{tabular}

Others direct human impact to the coral reef in this area, as mentioned in Jamal (2010), were the activities of destructive fishing method, sand and coral (for the limestone) mining, and coral organism collection for both aquarium ornaments and souvenir.

The case of coral reef condition at Tanjung Jumlai patch reef that discussed above has provide a flash description that coral reef in this area has being suffered from stress and degradation. In addition, more anthropogenic factors had affected the condition of Tanjung Jumlai patch reef rather than non- anthropogenic factors. Thus, it requires more specific, intense, and continued effort of monitoring and management toward the coral reef ecosystem at Tanjung Jumlai patch reef and performed in integrated programs and stakeholders.

\section{CONCLUSIONS}

Patch reef of Tanjung Jumlai consisted of five spots of sandbars with total of 346.58 ha with coral growth till \pm $7 \mathrm{~m}$ depth and the substratum was dominated by hard coral life form of ACB, ACT, and CF, and abiotic of S and R.
Live coral coverage varied from the lowest $\mathrm{LC}=5 \%$ at ST 7 (categorized as poor/bad) till the highest $\mathrm{LC}=78 \%$ at ST 6 (categorized as excellent), while average $\mathrm{LC}=42.5 \%$ was categorized as fair/moderate coral condition. The average coral mortality index (MI) was 0.34 , the lowest MI was 0.06 occurred at ST 6 and the highest MI occurred at ST 7.

Coral reef at Tanjung Jumlai patch reef was affected by many factors i.e.: wind and hydrodynamic, tides, turbidity and sediment loads, and human activities such as development at the mainland and Balikpapan Bay, destructive fishing method, sand and coral mining, and biota collecting.

\section{REFERENCES}

[1] Edinger, E. N., and M. J. Risk. 2000. Reef Classification by Coral Morphology Predicts Coral Reef Conservation Value. Biological Conservation 92: 1-13.

[2] Edinger, E.N., J. Jompa., G.V. Limon., W. Widjatmoko and M.J. Risk, 1998. Reef Degradation and Coral Biodiversity: Effects of land-based pollution, destructive fishing practices, and changes over time. Marine Pollution Bulletin 36, 617-630. 
[3] English, S., C. Wilkinson., and V. Baker. 1994. Survey Manual For Tropical Marine Resources. Australian Institute of Marine Science. Townsville, Australia.

[4] Gomez, E. D., and H. T. Yap. 1988. Monitoring Reef Condition. In: Kenchington, R. A., and B. E. T. Hudson. (Eds.), Coral Reef Management Handbook. UNESCO Regional Office for Science and Technology for Southeast Asia (ROSTSEA). Jakarta.

[5] Gomez, E. D., P. M. Alino., H. T. Yap., and W. Y. Licuanan. 1994. A Review of the Status of Philippine Reefs. Marine Pollution Bulletin 29:62-68

[6] Hill, J., and C. Wilkinson. 2004. Methods for Ecological Monitoring of Coral Reefs, Version 1; A Resource for Managers. Australian Institute of Marine Science. Australia.

[7] Jamal, E. 2010. Phenomenon of Coral Reef and The Ecosystem of Tanjung Jumlai Sandbar. SIKU Penajam Paser Utara; August 11th, 2010.

[8] Jompa, H., and L. Pet-Soede. 2002. The Coastal Fishery in East Kalimantan - A Rapid Assessment of Fishing Patterns, Status of Reef Habitat and Reef Fish Stocks and Socio-economic Characteristics,
First Draft - February 2002. WWF Indonesia - Wallacea Program. Denpasar, Bali.

[9] Kelompok Kerja Erosi dan Sedimentasi. (2002). Study of Erosion and Sedimentation at River System of Balikpapan Bay East Kalimantan, Technical Report of Proyek Pesisir, TE-02/13-I, CRC/URI. Jakarta.

[10] MacKinnon, K., G. Hatta., H. Halim., and A. Mangalik. 2000. The Ecology of Indonesian Series; Vol. III: Ecology of Kalimantan. Prenhallindo. Jakarta.

[11] Sadhukhan, K., and C. Raghunathan. 2011. Diversity and Abundance of Sclaractinia Corals in Car Nicobar Island, India. International Journal of Plant, Animal and Environmental Sciences. Vol. 1, Issue: 3 Sept-Nov 2011: 150-157.

[12] Sinaga, A. T., A. Satriadi., Hariyadi., and F. Novico. 2013. Distribution Pattern of Suspended Sediment Based on Tidal Current Pattern in Balikpapan Bay Waters East Kalimantan. Jurnal Oseanografi, Vol. 2, No.3. 2013: 329-336.

[13] Tomascik, T., A. J. Mah., A. Nontji., and M. K. Moosa. 1997. The Ecology of Indonesian Series; Vol. VII The Ecology of Indonesian Seas. Periplus Editions (HK) Ltd. Republic of Singapore. 